\title{
A Multivariate Analysis of Morphometric and Exosomatic Characters of Iguanid Lizards of the Patagonian Liolaemus kingi Complex
}

Jose A. Scolaro, Centro Nacional Patagonico, Conicet, Puerto Madryn, Argentina.

Jose M. CEI, Dpto. Ciencias Naturales, Universidad Nacional de Rio Cuarto, Cordoba, Argentina, and Rancho Somuncura, Rua Fausto de Figueiredo, Birre 2750, Cascais, Portugal.

For more than a century Liolaemus kingi (Bell, 1843) has been reported as a classical viviparous Patagonian iguanid, widely distributed in southern Chubut and Santa Cruz Provinces (Cei, 1975). In addition to the nominate form, two other localized forms of this group have been discovered (Cei and Scolaro, 1981, 1983). Paying attention to their morphological similarities with $L$. Kingi kingi, and pointing out the quite evident condition of allopatry in both cases, the authors described L. kingi somuncurae and L. kingi baguali as subspecies, from the Somuncurá plateau of Rio Negro, and the Sierra Bagual, Santa Cruz, respectively. However, their peculiar physiognomy and the specialized conditions of the habitats justified additional research on morphological and evolutionary relationships of these still poorly known tropidurine lizards. We here assess the reciprocal position of the members of the L. Kingi complex by means of multivariate analysis of their morphometric and exosomatic characters.

Specimens used in this study were collected on 


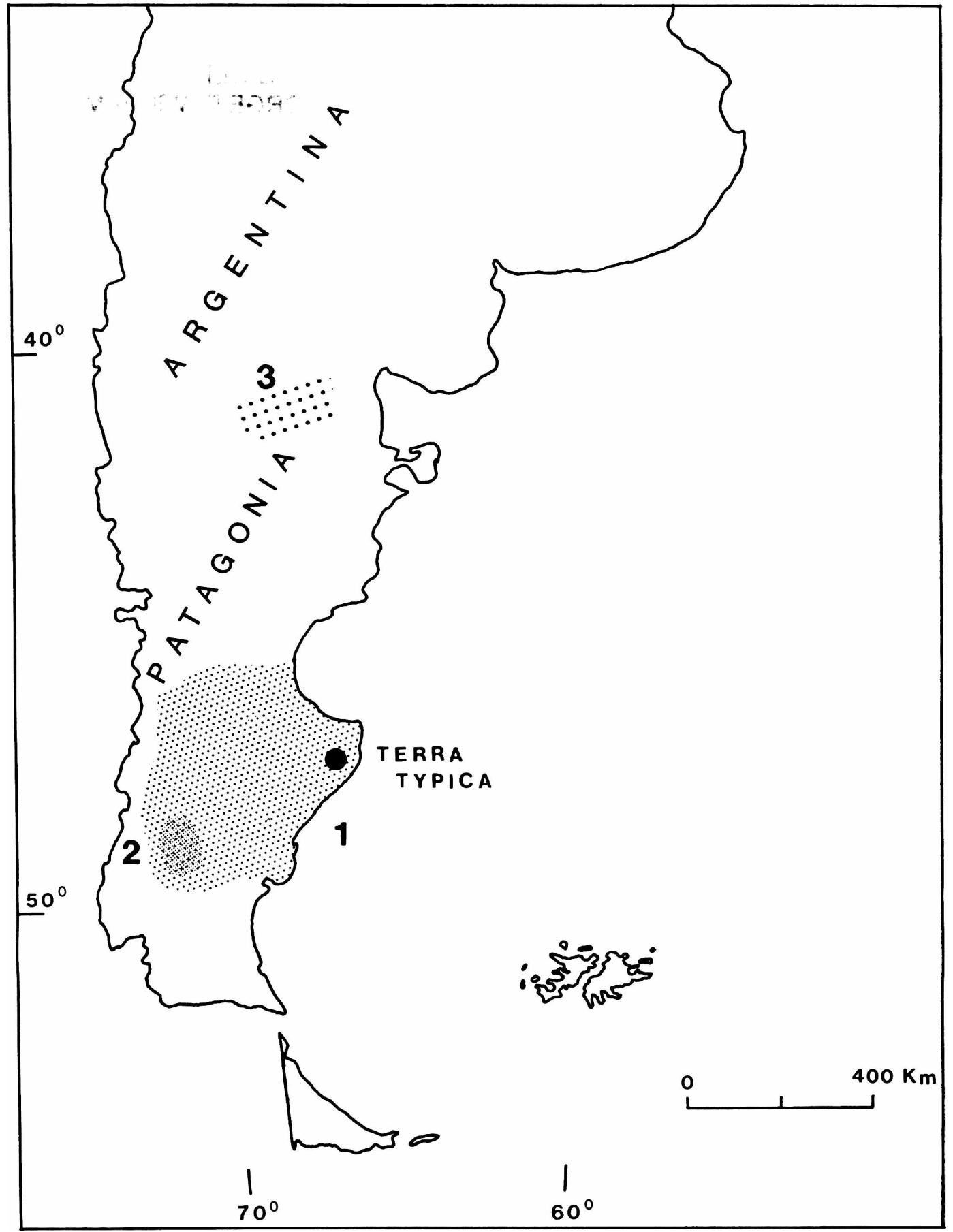

Fig. 1. Distribution map of the three populations: 1. Liolaemus kingi kingi, 2. L. kingi baguali and 3. L. kingi somuncurae. 


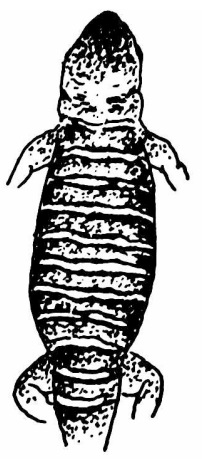

A

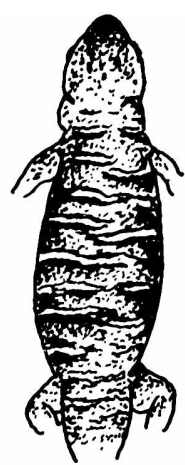

20

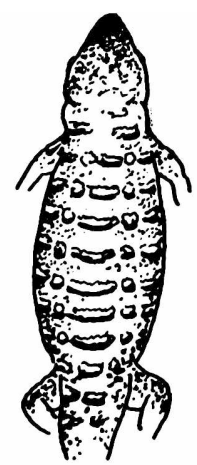

40

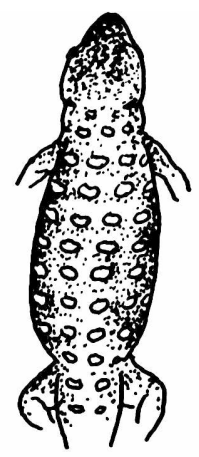

60

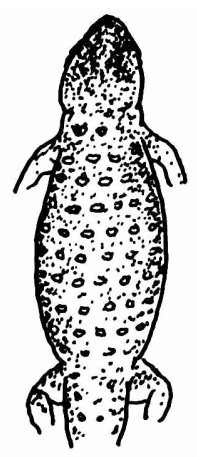

80

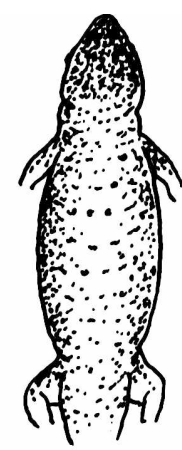

100

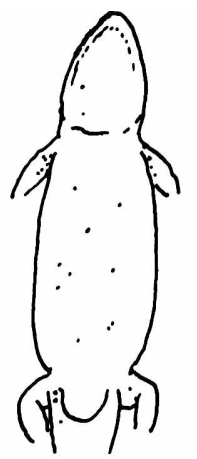

0

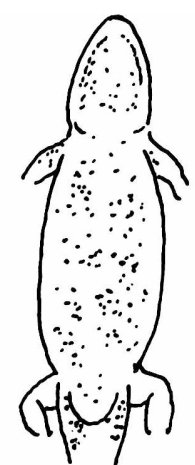

25

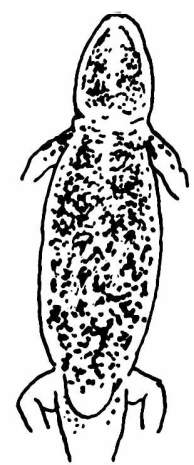

50

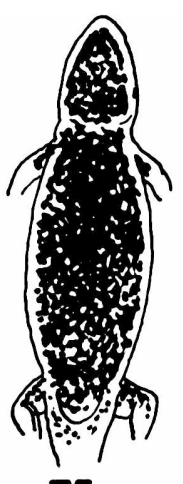

75

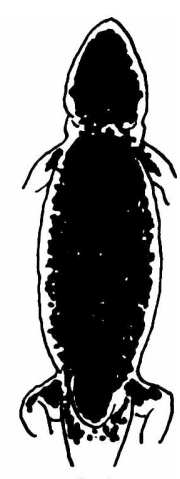

100

FIG. 2. Arbitrary scale of discontinuous variables referable to the dorsal stripe pattern (A) and to the ventral pigmentation (B), in Liolaemus kingi group. A: 0-Regular transverse light stripes; 20-Less regular, often broken light stripes; 40-Alternate, whitish streak and dot bands; 60-Transverse whitish dot lines; $80-$ Transverse whitish points, not too evident; 100 -Almost indistinguishable transverse whitish points. (0: typical L. kingi baguali pattern; 100: typical L. kingi somuncurae pattern). B: 0-Very scarce chromatophores; 25-More evident scattered chromatophores; 50-Darker, often marble, obscure pigmentation; 75-Very dark, almost melanic, ventral pigmentation; 100-Melanic belly. (100: typical of L. kingi baguali).

many field trips in the Patagonian region of Argentina through 1980-1985 (Fig. 1). The 59 individuals assembled represent: $L$. kingi somuncurae $(\mathrm{N}=14)$ from the volcanic Somuncurá plateau; $L$. kingi baguali $(\mathrm{N}=$ 17) from Sierra Bagual, Santa Cruz Province; and $L$. kingi kingi $(\mathbf{N}=28)$ from Fitz Roy, Deseado, Meseta Central, Perito Moreno, Tuco-Tuco and Gregores, all localities of the Santa Cruz Province (from $47^{\circ}$ to $49^{\circ}$ South lat.). The specimens belong to the herpetological collections of the MZUF (Museo Zoologico Universitá di Firenze, Italy), KU (Museum of Natural History, University of Kansas), MLP (Museo de la Plata, Argentina) and JMC-DC (J. M. Cei-Diagnostic Collection).

All morphometric measurements were taken on adult specimens, whose maturity was determined by dissection. Continuous and discontinuous variables were selected in accordance with the previous descriptions of the above mentioned taxa (Cei, 1975; Cei and Scolaro, 1981, 1983). A numerical evaluation of chromatic patterns in the established groups was added to the statistical treatment with discontinuous variables. These variables, arranged according to an arbitrary numerical scale, applied by careful comparative observations, are summarized in Fig. 2. They are "dorsal stripe pattern" and "ventral pigmentation," referring to the number, shape and size of light, white or yellow, dorsal bands, and to the relative chromatophore density on throat and venter.

All the data were treated by means of two discriminant analyses (Foucart's method: 1982). Initially, 14 continuous and discontinuous variables were used. From these, a set of 9 significant variables were selected, whose further analysis are reported in this 
TABLE 1. Comparative mensural characters in $L$. kingi subspecies. Values represent mean and standard deviation (SD).

\begin{tabular}{lccc}
\hline \hline \multicolumn{1}{c}{ Variables } & $\begin{array}{c}\text { Liolaemus kingi } \\
\text { somuncurae }(\mathrm{N}=14)\end{array}$ & $\begin{array}{c}\text { Liolaemus kingi baguali } \\
(\mathrm{N}=17)\end{array}$ & $\begin{array}{c}\text { Liolaemus kingi kingi } \\
(\mathrm{N}=28)\end{array}$ \\
\hline Head width (mm) & $13.23(1.08)$ & $13.86(1.20)$ & $13.91(1.87)$ \\
Hind limb length (mm) & $39.06(2.56)$ & $41.12(2.62)$ & $38.42(4.39)$ \\
Fore limb length (mm) & $24.39(2.02)$ & $25.42(1.93)$ & $23.47(2.20)$ \\
Axilla-groin length (mm) & $38.01(4.52)$ & $38.99(4.45)$ & $40.12(4.34)$ \\
Fourth toe lamellae & $24.50(2.19)$ & $24.65(1.45)$ & $23.39(2.61)$ \\
Scale number around midbody & $79.14(3.02)$ & $81.12(2.87)$ & $80.11(5.07)$ \\
Supralabial scale number & $8.50(0.50)$ & $8.18(0.62)$ & $8.75(0.78)$ \\
Dorsal stripe pattern & $90.00(14.64)$ & $20.00(5.94)$ & $36.43(7.66)$ \\
Ventral pigmentation (\%) & $53.57(8.75)$ & $95.59(9.53)$ & $52.68(22.50)$ \\
\hline
\end{tabular}

paper. The considered variables, besides "dorsal stripe pattern" and "ventral pigmentation," are: "head width," "hind limb length," "fore limb length," "axilla-groin length," "fourth toe lamellae," "scale number around midbody" and "supralabial scale number." When the groups were compared, the means of each variable were tested in accordance with their type distribution ( $F$ Snedecor test). In the case of Gaussian normal distribution, the $t$ Student test was applied; in no Gaussian distribution the " $U$ " MannWhitney test was used.

A first discriminant analysis provided the association of the variables to the two main canonic axes obtained for the 3 subspecific groups considered. The second discriminant analysis yielded similar discrimination between groups, and a similar percentage of well classified cases was again obtained (Table 1).

The discriminant analysis supports the correlation matrix between variables (Table 2) and shows two canonic axes. The canonic axis I absorbs $57 \%$ of the total variance, and the canonic axis II the remaining
43\%. The canonic axis I associates, with the most significance, the variables "dorsal stripe pattern" (positively), and "scale number around midbody" (negatively). Such an axis allows separation of $L$. kingi somuncurae from the remaining groups by a major expression of the former variable $(P<0.001, t$ Student test) and a minor expression of the latter $(P<0.05$, " $U$ " Mann-Whitney test).

The canonic axis II associates, with the highest significance, the following variables: "fore limb length," "ventral pigmentation" and "fourth toe lamellae" (all positively), and "supralabial scale number" (negatively). This axis allows separation of L. kingi baguali from the other forms. Moreover, the canonic axis II strengthens the difference between $L$. kingibaguali and L. king $i$ king $i$ by means of the following variables with a major expression in the former taxon: "fore limb length" $(P<0.001$, " $U$ "Mann-Whitney test), "ventral pigmentation" $(P<0.001, t$ Student test $)$, and "fourth toe lamellae" $(P<0.05$, "U" Mann-Whitney test). On the other hand, the variable "supralabial scale num-

TABLE 2. Correlation ( $r$ matrix between variables of Table 1.

\begin{tabular}{|c|c|c|c|c|c|c|c|c|}
\hline Variables & $\begin{array}{l}\text { Hind } \\
\text { limb } \\
\text { length }\end{array}$ & $\begin{array}{l}\text { Fore } \\
\text { limb } \\
\text { length }\end{array}$ & $\begin{array}{l}\text { Axilla- } \\
\text { groin } \\
\text { length }\end{array}$ & $\begin{array}{c}\text { Fourth } \\
\text { toe } \\
\text { lamellae }\end{array}$ & $\begin{array}{l}\text { Scale } \\
\text { number } \\
\text { around } \\
\text { midbody }\end{array}$ & $\begin{array}{l}\text { Supralabial } \\
\text { scale } \\
\text { number }\end{array}$ & $\begin{array}{l}\text { Dorsal } \\
\text { stripe } \\
\text { pattern }\end{array}$ & $\begin{array}{c}\text { Ventral } \\
\text { pigmen- } \\
\text { tation }\end{array}$ \\
\hline Head width & $\begin{array}{l}0.78 \\
* * *\end{array}$ & 0.62 & $\underset{* *}{0.37}$ & 0.27 & $\underset{*}{0.27}$ & 0.18 & -0.13 & 0.01 \\
\hline Hind limb length & & $\begin{array}{l}0.77 \\
* * *\end{array}$ & $\underset{*}{0.31}$ & 0.40 & $\underset{*}{0.32}$ & 0.05 & -0.08 & 0.14 \\
\hline Fore limb length & & & 0.21 & $\begin{array}{c}0.36 \\
* *\end{array}$ & $\underset{*}{0.31}$ & 0.06 & -0.06 & 0.18 \\
\hline Axilla-groin length & & & & 0.03 & 0.14 & 0.08 & -0.17 & -0.06 \\
\hline Fourth toe lamellae & & & & & 0.23 & 0.01 & 0.06 & -0.12 \\
\hline Scale number around midbody & & & & & & -0.18 & -0.18 & 0.04 \\
\hline Supralabial scale number & & & & & & & 0.05 & -0.36 \\
\hline Dorsal stripe pattern & & & & & & & & -0.42 \\
\hline
\end{tabular}

*P<0.05; $* P<0.01 ; * * P<0.001$. 


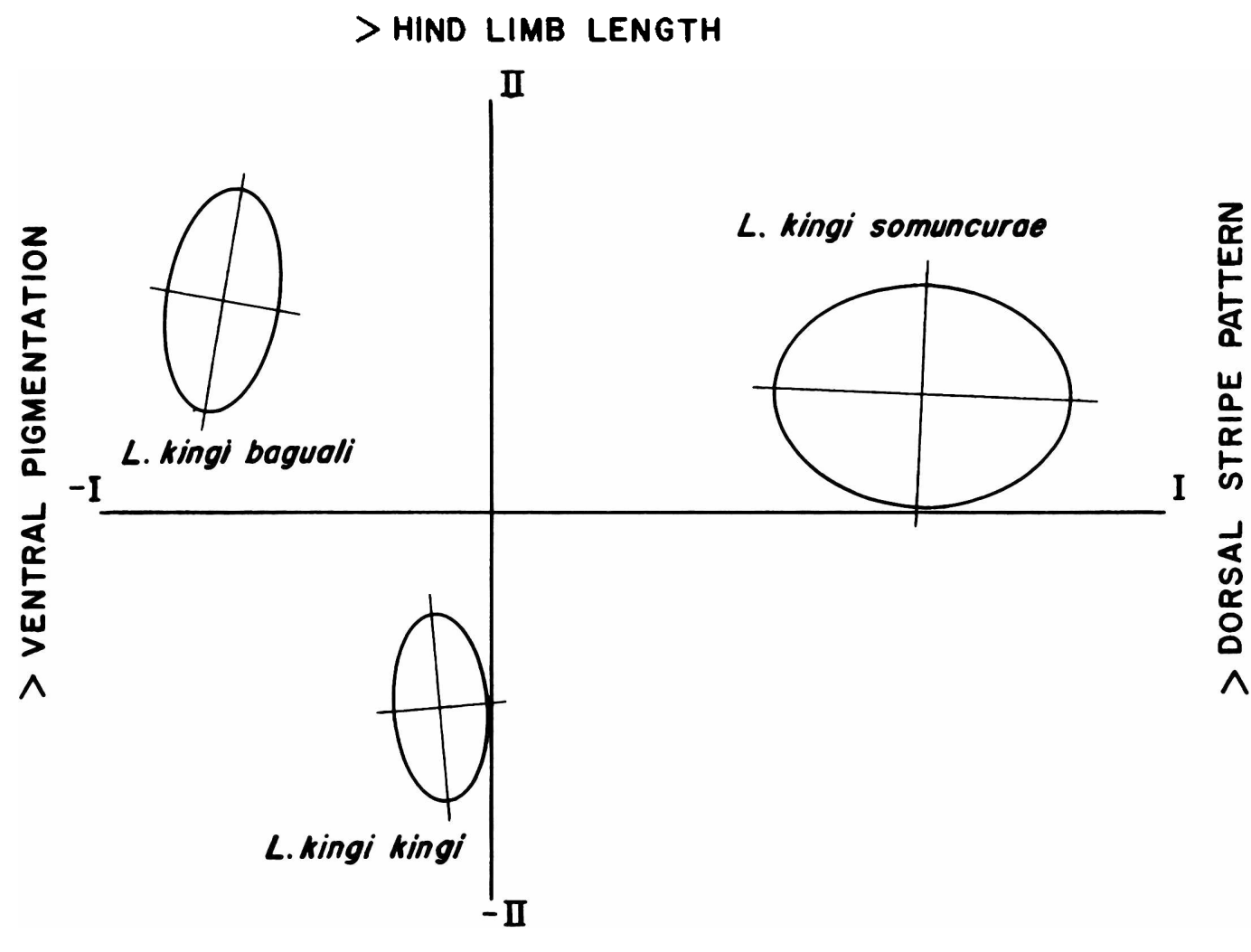

< HIND LIMB LENGTH

FIG. 3. Ellipses of equiprobability for all the cases $(P<0.01)$.

ber" exhibits a minor expression in L. kingi baguali $(P<0.01$, " $U$ " Mann-Whitney test). If the means of the remaining variables are compared, $L$. kingi somuncurae versus $L$. kingi kingi shows a major expression for the variable "fore limb length" $(P<0.05$, " $U$ " Mann-Whitney test). However, L. kingi somuncurae versus $L$. kingi baguali shows a minor expression for the variables "hind limb length" $(P<0.05$, " $U$ " MannWhitney test) and "ventral pigmentation" $(P<0.001$, " $U$ " Mann-Whitney test). Comparing $L$. kingi baguali and $L$. kingi kingi, a major expression of the variable "hind limb length" $(P<0.05, t$ Student test $)$ and a minor expression of "dorsal stripe pattern" $(P<0.001$, " $U$ " Mann-Whitney test) are evident for the former taxon.

Discriminant analysis of individual specimens resulted in a very high percentage of correct classification $(98.31 \%)$. Ellipses of equiprobability $(P<0.001$ : Sokal and Rohlf, 1979) for all specimens revealed no overlap between the considered groups (Fig. 3). A major distance between ellipse centroids was shown in comparison of $L$. kingi somuncurae and $L$. kingi baguali, whereas $L$. kingi king $i$ appeared to be nearer and approximately equidistant from both these forms.

The reported results stress a noticeable distance between all the presently known tropidurine lizards of the Liolaemus kingi complex, as suggested by the clear- cut separation of the population groups assembled by the respective ellipses of equiprobability. The major difference is shown by $L$. kingi somuncurae versus $L$. kingi baguali, conforming with the endemism of both forms at the extreme boundaries of the whole distribution area of the complex (Fig. 1). The nominate form is approximately equidistant from the others, but slightly nearer $L$. kingi baguali than $L$, kingi somuncurae. While a true allopatric condition, and an impressive latitudinal gap, can be pointed out for L. kingi somuncurae and L. kingi kingi, the Sierra Bagual range, home of $L$. kingibaguali, appears totally included within the very extensive area of this latter. It implies some mechanisms of topographic and ecological isolation, making gene flow difficult between the specialized basaltic rock inhabitant L. kingi baguali, and the widespread and ecologically more opportunistic L. kingi kingi, found in very different environments, even sandy shores.

Results of the present multivariate analysis, together with the distribution patterns, could suggest a probable high degree of evolutionary divergence, supported in the case of $L$. kingi somuncurae by a relatively long geological period of isolation, strengthened by physiographic barriers. In the case of L. kingi baguali, environmental factors may account for its morphological and perhaps genetic separation from 
L. kingi kingi, in spite of possible but not proved sympatry suggested by the close approximation of their distributional boundaries. Thus, because of the allopatry of these taxa, so far as now known, we prefer for the moment not to propose nomenclatural changes, in spite of the significance of the discriminant analysis, which could justify postulation of specific status either for L. kingi baguali or L. kingi somuncurae. At any rate, a condition of "incipient species," sensu Mayr (1963), may be reasonably envisioned for these lizards.

Acknowledgments. - We are indebted to J. Upton (CENPAT-CONICET) for his constant aid during our Patagonian field work. We thank L. Arias de Reyna for his helpful statistical comments and the reviewers whose criticisms and suggestions greatly improved the manuscript. Special thanks are due to Graciela de Candia and her collaborators (Area Comunicación Visual, CRICYT, Mendoza) for their assistance in preparing figures and graphs.

\section{Literature Cited}

CEI, J. M. 1975. Southern Patagonian iguanid lizards of the Liolaemus kingi group. Herpetologica 31:109116.

Cei, J. M., and J. A. Scolaro. 1981. A new northern subspecies of Liolaemus kingi in Argentina. J. Herpetol. 15:207-210.

and

1983. Una nueva forma geográfica de Liolaemus kingi de Santa Cruz, Argentina (Lacertilia, Iguanidae). Neotropica 29(82):209-214.

FouCART, T. 1982. Analyse factorielle. Programmation sur microordinateurs. Masson, Paris. 245 pp.

MAYR, E. 1963. Animal Species and Evolution. Harvard Univ. Press, Cambridge, Mass. 797 pp.

SoKal, R. R., AND F. J. Rohlf. 1979. Biometria. Principios y métodos estadísticos en la investigación biológica. Blume, Madrid. 832 pp.

Accepted: 26 June 1986. 